3)校正

（独）放射線医学総合研究所 石川徽夫

・ラドン測定標準化専門研究会の提言

(財) 日本分析センター 真田哲也

\section{- 意見交換}

第 2 部 ラドンの防護規準に関する専門研究会

・ラドンの対策レベルに関する国際動向（WHO,

\section{1.はじめに}

2010 年 3 月 3 日, 東京大学アイソトープ総合センター に扔いて，「ラドン測定標準化及び関連の国際動向に関 するシンポジウム」が開催された。同シンポジウムは「ラ ドン測定標準化専門研究会」と「ラドンの防護基準に関 する専門研究会」による合同開催で，ラドン測定標準化 専門研究会のとりまとめた報告書について紹介するとと もに，提言について広く意見を求め, 最終的な報告書に 反映させること，及び，ラドンに関するWHO，ICRP， IAEA 等の国際的な最近の情報を共有すること，を目的 として行われた。私は, ラドン測定標準化専門研究会に オブザーバーとして一度参加させて頂いたことがあり， また, 同研究会が実施したラドン濃度測定の国際相互比 較試験にも自社製の CR-39（固体飛跡検出器）を組み込 んだ測定器を用いて参加したことがある。今回，ラドン 測定に関する最新の情報を得るため，シンポジウムに参 加したので，その内容について簡単に紹介する。

\section{2. シンポジウムのプログラム}

第 1 部 ラドン測定標準化専門研究会

座長 : 神戸薬科大学 安岡由美

・ラドン測定標準化専門研究会の意義及び国際的な動 向

（独）放射線医学総合研究所 床次眞司 ・ラドン測定標準化に係る国内の動向

（独）日本原子力研究開発機構 石森 有

・測定法に係るレビュー

1)ラドン（大気中・散逸・水中）

神戸薬科大学 安岡由美

2)壊変生成物

（株）日立製作所 北口博司

Wakako ShINozAKI: Symposium on Radon Measurement Standardization and Relevant International Trends.

*1 (株) 千代田テクノル；茨城県東茨城郡大洗町成田町 3681 ( ₹ 311-1313)

Oarai Research Center, Chiyoda Technol Corporation; 3681, Naritacho, Oarai-machi, Higashi-ibaraki-gun, Ibaraki 311-1313, Japan.
IAEA, ICRP)

(独) 放射線医学総合研究所 米原英典 ・ コメント 1 保健物理学会における関連の過去の活 動

藤田保健衛生大学 下 道国

・コメント 2 ラドン防護規準に関する専門研究会の 活動予定

名古屋大学 飯田孝夫

・意見交換

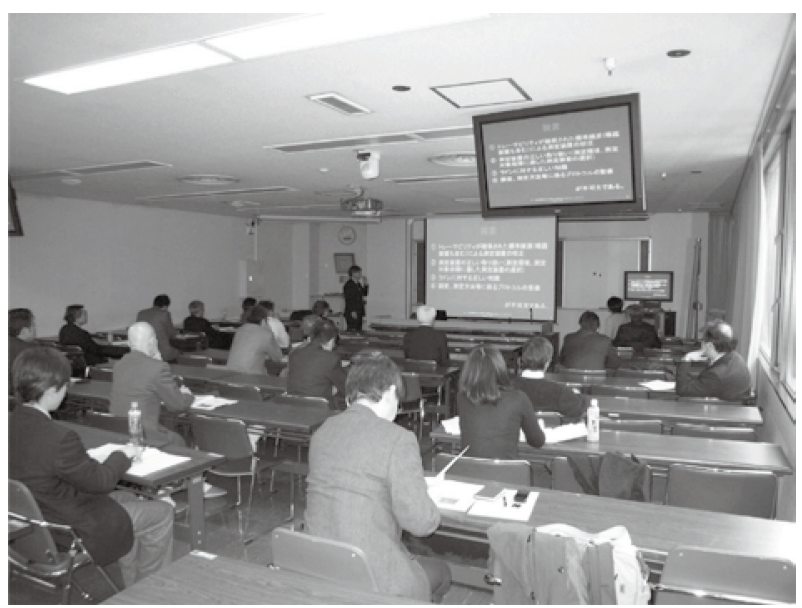

第 1 図会場の様子

\section{3. 講演内容について}

ラドン測定標準化専門研究会の活動と国内外の動向

ラドン測定標準化専門研究会は，ラドン測定に係る標 準的な手法を提案し, 技術上の課題を明確にすることで, 将来的な日本の国家標準の確立に貢献することを目的に 設立され，平成 20 年度から平成 21 年度まで活動した。 具体的な活動内容として，(1)標準測定法の検討，(2)わが 国のラドンに関する国家標準の体系化の議論, (3)国際標 準規格に対して日本の意見を反映させる，等を設定し， これまで計 3 回の研究会を開催してきた。

ラドンに関する国際的な動向を見ると, 国際規格では, 
現在 ISO, IEC がラドン等の測定法や装置に関する規格 文書を改訂中であり, さらに, 水中ラドン測定法につい ても新規提案が行われている。

ラドン測定標準化に係る国内の動向については, ラド ン測定に係る国家標準は現在まだ検討段階であり，(独） 産業技術総合研究所 (産総研) でラドン標準線源を作成 するなどの試みはなされているものの, 具体的な取り組 みには至っていない状況である。したがって，国内には ラドンの国家標準としての標準場や JIS 等で定められた 標準法が無いため, (独) 日本原子力研究開発機構 (JAEA) と(独) 放射線医学総合研究所 (NIRS) では, それぞ れ独自にトレーサビリティの確立と標準場の確立を行っ ている。NIRSでは, これまで, 2007 年, 2008 年, 2010 年と, 3 度のラドン測定の国際相互比較試験を実施して きた。国際的に，ラドン測定器の校正にはまだ課題が残 されていると報告があり, 今後も比較校正実験の継続的 な実施が望まれている。また，（財）日本分析センター では, 全国の屋内及び屋外のラドン濃度調查を, 環境科 学技術研究所では青森県におけるラドン濃度調查を実施 してきたことから，JAEA やNIRS の標準場を利用して, 組織的な標準化を行ったことが紹介された。

\section{測定法に関するレビュー}

ラドンの主な測定法に関して, 大気中, 散逸率, 水中 のラドン測定について, それぞれ使用される測定器とそ の特徵が紹介された。測定器の選択条件は, 対象とする 試料, ラドン濃度, 評価すべき值（瞬間值か平均值か）, 測定の規模（ポイント数）等によって決まる。大気中の 測定には, シンチレーションセル法やガス封入型電離箱 法, 固体飛跡検出器を利用した積分測定法などが用いら れる。散逸率の測定には蓄積法が, 水中ラドンの測定に は, 大気中ラドン測定法で測定する方法と, 液体シンチ レーションカウンタを用いる方法が一般的である。また, $\mathrm{Rn}$ 壊変生成核種の測定法については, $\mathrm{ZnS}(\mathrm{Ag})$ シン チレーション検出器を用いたグロス計数法と $\mathrm{Si}$ 半導体 検出器を用いた $\alpha$ 線スペクトロメトリー法などが紹介さ れた。

\section{ラドン測定標準化専門研究会の提言}

ラドン及びその壊変生成物の正確な測定について，ラ ドン測定標準化専門研究会の提言は以下の通りである。 提言(1)

現在整備されている曝露装置打よびトレーサビリ ティ体系の維持, 産総研による国家標準体系の確立
が必要不可欠である。

提言(2)

測定装置の正しい取り扱い, 測定環境, 測定対象 核種に適した測定装置の選択が必要である。 提言(3)

ラドンの性質, 特徴の理解, 測定技術の習得が必 要である。ラドン濃度測定に関して, 実績のある専 門機関による教育訓練を実施すべきである。

提言(4)

調査体制の整備（トレーサビリティの明確化を含 む), 測定方法等の整備（マニュアルの整備）が必 要である。

これに関しては他分野との連携が重要である。ま た, ラドンの歴史の理解も必要である。ラドンは日 本では温泉として親しまれているので, 技術的な視 点のみで検討・規制を進めると理解を得るのが難し くなる。一般の人が理解できるような説明が必要で ある。

最後に, ラドン測定は日本の技術がアドバンテー ジを握っているが, しかし, 日本からの発信は十分 でない。日本が世界に誇れる分野であることを強調 し, 国際的な舞台での日本人の活躍を期待すると述 ベられた。

\section{ラドンの防護規準に関する専門研究会}

ラドンの防護規準に関する専門研究会は, ラドンの線 量規準に関して, その具体的な現場運用について参考と なる資料の優先順位や策定に倸る手順を検討し，最新の 国内外の動向に注意しつつ, 日本の状況に適合した資料 の策定を実施するために設置された。

ラドンの対策レベルに関する国際動向として, ラドン 被ばくに関するガイドラインの策定と有効なリスク低 減策の提供のため, 2005 年に発足したWHO の国際ラ ドンプロジェクト（IRP）の活動についての報告があっ た。IRPの会合は, 27 か国からラドンの専門家 60 数名 の参加により,これまで 3 回開催され, 2009 年 9 月には, 屋内ラドンに関するハンドブックリを発行した。

日本保健物理学会に扔ける関連の過去の活動について も紹介された。「ラドン・トロン研究専門委員会 (調査)」 （1984 年 4 月〜 1986 年 3 月）にはじまり，「ラドン・ト ロン研究専門委員会（ラドンとその娘核種－測定と較正 -)」(1986 年 4 月〜 1988 年 3 月),「ラドンの人体への 影響評価研究専門委員会」(1996 年 4 月～ 1998 年 3 月), 「人為的に高められた環境放射線専門研究会」(2000 年 
4 月〜 2002 年 3 月), 「水中ラドンに関する専門研究会」 (2002 年 4 月〜 2004 年 3 月), 「ラドン测定標準化専門 研究会」(2008 年 4 月〜 2010 年 3 月),「ラドンの防護 規準に関する専門研究会」(2009 年 10 月～ 2011 年 3 月) と, これまでに多くの研究専門委員会, 専門研究会によ る活動を行ってきた。

当該研究会では, 今後の活動方針として，過去のデー 夕・成果の再整理及び検討を行い, 問題点・課題の抽出, 放射線防護標準化委員会のガイドラインを参考として今 後の課題の検討, ICRP のラドンタスクグループ, IAEA などへの意見表明・提言の検討等を行っていくと述べら れた。

所感

今回シンポジウムに参加して，ラドンに関する日本の 技術力の高さ，国内外の動向を良く知ることができ，大 変勉強になった。また，積極的な意見交換ができる環境
は素晴らしいと思った。シンポジウム内でも言われてい た通り，是非この技術力を世界に主張し発信していって 欲しい。

最後に, シンポジウム参加の機会を与えてくださった, 日本保健物理学会, 企画委員会に御礼申し上げます。

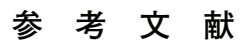

1) WHO; WHO HANDBOOK ON INDOOR RADON: A PUBLIC HEALTH PERSPECTIVE (2009)

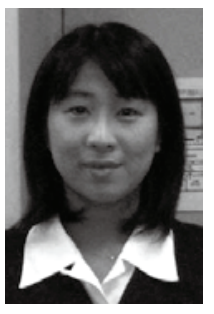

篠㟝 和佳子（しのざき わかこ）

平成 16 年（株）千代田テクノル入社。 大洗研究所研究員。現在, CR-39 個体飛 跡検出器を用いた中性子線量計の開発業 務に従事。趣味はキャンプ。

E-mail: shinozaki-w@c-technol.co.jp

\section{話 題}

\section{平成 21 年度放射能分析確認調査技術 検討会に参加して}

\section{竹原仁*}

\section{1.は じめに}

平成 21 年度放射能分析確認調査技術検討会（以下, 「技術検討会」という。）が平成 22 年 3 月 17 日（水）に 東京国際フォーラムにおいて, 文部科学省, 放射能分析 確認調査検討委員 (委員長: 富永健東京大学名誉教授), 地方自治体職員など約 100 名の参加を得て開催された。 筆者は平成 20 年度から放射能分析確認調查検討会委員 として検討会に参加しており，本稿では放射能分析確認 調査の概要と技術検討会の印象について報告する。

Hitoshi Takegahara: Participate in the Technical Meeting on Quality Assurance for Environmental Radioactivity Analysis in 2010

*1 青森県原子力センター; 青森県上北郡六ヶ所村倉内笹崎 400-1 ( T 039-3215)

Aomori Prefectural Nuclear Power Safety Center; 400-1 Sasazaki, Kurauchi, Rokkasho, Aomori 039-3215, Japan.

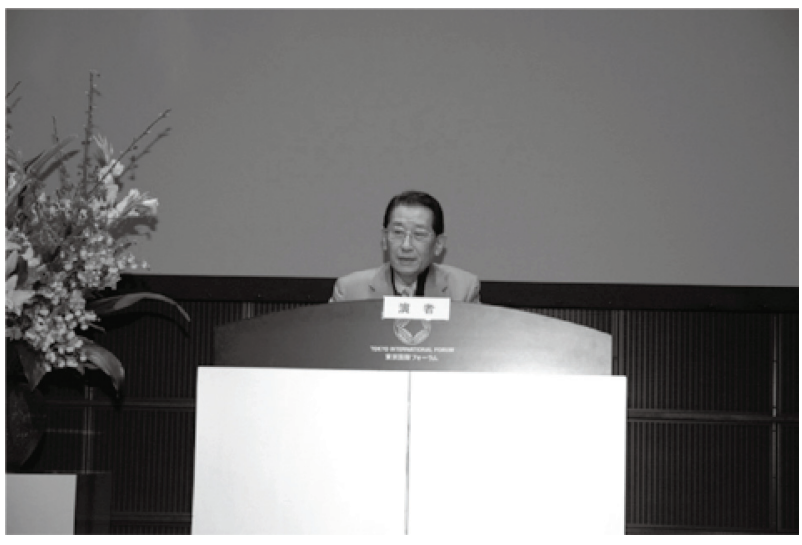

富永委員長の総評

\section{2. 放射能分析確認調査の概要}

放射能分析確認調査は, 文部科学省から委託を受けて （財）日本分析センターが実施している事業であり，全 国 47 都道府県の放射能調查機関（以下「分析機関」と いう。）を対象としている。

これは日本分析センターと分析機関が行う環境放射能 分析・放射線測定結果を相互に比較することにより，当 該都道府県が行う分析・測定結果の信頼性を確認すると ともに, 環境試料の採取, 前処理, 分析 - 測定法等一連 の環境放射能分析・放射線測定技術の向上に資すること を目的としている。 